Fox, H. (1965). f. Obstet. Gynaec. Brit. Cwlth, 72, 347.

Getzowa, S., and Sadovsky, A. (1950). ₹. Obstet. Gynaec. Brit. Emp., 57, 388 .

Griffiths, J. D., and Salisbury, A. J. (1965). Circulating Cancer Cells. Thomas, Springfield, Illinois.

Hagerman, D. D. (1964). Fed. Proc., 23, 785.

Hamilton, W J., and Boyd, J. D. (1950). Modern Trends in Obstetrics and Gynaecology, edited by K. Bowes, p. 114. Butterworth, London. (1951). Proc. roy. Soc. Med., 44, 489.

$--(1951)$. Proc. roy. Soc. Med., 44, 489.
- and Mossman, H. W. (1962). Human Embryology, 3rd ed. Heffer, Cambridge.

Hashimoto, M., Kosaka, M., Shimoyama, T., Hirasawa, T., Komori, A., Kawasaki, T. and Akashi, K. (1960). 'f. Fap. obstet. gynaec. Soc. (eng.), 7, 122 .

Herbeuval, R. and H. (1960). C.R. Acad. Sci. (Paris), 250, 3070.

Hertig, A. T. (1960). In Placenta and Foetal Membranes, edited by C. A Villee, p. 109. Williams and Wilkins, Boltimore.

Hörmann, G. (1951). Arch. Gynäk., 181, 29.

Hormann, G. (1953). Ibid., 184, 109.

Iklé, F. A. (1961). Schweiz. med. Wschr., 91, 943.

1964). Bull. schweiz. Akad. med. Wiss., 20, 62.

Ishizaki, Y. (1960). Obstet. and Gynec., 15, 602.

Kay, S., and Reed, W. G. (1953). Amer. F. Path., 29, 555.

Kubli, F., and Budliger, H. (1963). Geburtsh. u. Frauenheilk., 23, 37.

Langhans, T. (1882). In Fests. f. Henle Beitr. Anat. Embryol., 69.

Lister, Ursula M. (1963). F. Obstet. Gynaec. Brit. Cwlth, 70, 766.

- (1964). Ibid., 71, 21.

Mercer, R. D., Lammert, A. C., Anderson, R., and Hazard, J. B. (1958) f. Amer. med Ass., 166, 482.

Merrill, J. A. (1963). Clin. Obstet. Gynec., 6, 96.

Meyer, A. W. (1921). Contr. Embryol. Carneg. Instn., 12, 327.

Minot, G. R. (1922). 7. exp. Med., 36, 1.

Ortmann, R. (1938). Z. Anat. Entwickl-Gesch., 108, 427.

Panigel, M., and Anh, J. N. (1963). C.R. Acad. Sci. (Paris), 257, 3669.
Park, W. W. (1954). F. Path. Bact., 67, 563.

(1959). In Modern Trends in Pathology, edited by D. H. Collins, p. 180. Butterworth, London.

(1965). The Early Conceptus, Normal and Abnormal, p. 74. Livingstone, Edinburgh.

Salvaggio, A. T., Nigogosyan, G., and Mack, H. C. (1960). Amer. f. Obstet. Gynec., 80, 1013.

Sauramo, H. (1951). Ann. Chir. Gynaec. Fenn., 40, 164

Schmorl, G. (1893). Pathologische-anatomische Untersuchungen über Puerperal-Eklampsie. Vogel, Leipzig.

Schramm, B. (1962). Gynéc. et Obstét., 61, 423.

Shanklin, D. R. (1958). Obstet. and Gynec., 11, 129.

Snoeck, J. (1958). Le Placenta Humain. Masson, Paris.

Strauss, F. (1964). Fortschr. Geburtsh. Gynäk., 17, 3.

Tao, T. W. (1964). Exp. Cell Res., 36, 275.

Thomas, L. (1961). In Ist International Conference Congenital Malforma-

tions, p. 230. Lippincott, Philadelphia. Dhycns, 72, 140 .

Veit, J. (1905). Die Verschleppung der Chorionzotten (Zottendeportation). Ein Beitrag zur geburtshilfichen Physiologie und Pathologie. Bergmann, Wiesbeden.

Velardo, J. T., and Rosa, C. G. (1963). Handuchb der Histochimie, 7/iii, 1. Fischer, Stuttgart.

Virchow, R. (1853). Verh. phys.-med. Ges. Würzb., 4, 370.

(1856). Gesammelte Abhandlungen zur wissenschaftlichen Medicin. Meidinger, Frankfurt.

- (1862). Ibid., 2nd ed. Grote, Hamm.

Wachstein, M., Meagher, J. G., and Ortiz, J. (1963). Amer. F. Obstet. Gynec., 87, 13.

Wilkin, P. (1965). Pathologie du Placenta. Masson, Paris.

Wislocki, G. B., and Bennett, H. S. (1943). Amer. f. Anat., 73, 335

- and Dempsey, E. W. (1955). Anat. Rec., 123, 133. and Padykula, Helen A. (1961). In Sex and Intenal Secretions, edited by W. C. Young, 3rd ed., p. 883. Williams and Wilkins, Baltimore.

\title{
Lung Cancer and Bronchitis in Northern Ireland, 1960-2
}

\author{
GEOFFREY DEAN,* M.D., F.R.C.P.
}

Brit. med. F., 1966, 1, 1506-1514

This paper summarizes the results of a retrospective epidemiological study of men and women who died of lung cancer or bronchitis during the years 1960-2 in Northern Ireland. The purpose of the study was to obtain information about the extent of the associations with lung cancer and bronchitis of smoking habits, area of residence, occupation, social class, month of birth, morning cough three or more years before death, illnesses during the last 10 years of life, and the incidence of cancer and bronchitis among parents, brothers, or sisters of those who died from lung cancer or bronchitis. Northern Ireland was chosen as the area to be studied, since the objective was to cover so far as was possible all the men and women aged 35 or more who had died of lung cancer or bronchitis during a recent period in a moderately large area of the United Kingdom. In this study $93 \%$ coverage was obtained.

Through the courtesy of the Registrar-General a list was obtained, for confidential use in the investigation, of all Northern Ireland residents aged 35 years or more who were recorded in the Register of Deaths as having died of lung cancer or bronchitis in Northern Ireland during 1960, 1961, and 1962. For each of these subjects a "control" was selected, who was the next person in the Register of Deaths of the same sex in the same five-year age group, who last resided in the same type of area, and who died of a non-respiratory illness. Personal interviews were then sought with the relatives of all those on the lists by trained women interviewers of the Health Surveys Unit of AGB Research Ltd. during January-July 1964. During 1960-2 873 male and 167 female residents aged 35 or more had died of lung cancer, and 1,262 males and 630 females

\footnotetext{
* Senior Physician, Eastern Cape Provincial Hospital, Port Elizabeth,
}

had died of bronchitis, in Northern Ireland. Including controls, this gave a total of 5,864 interviews to be carried out.

For the purposes of the present study Northern Ireland was divided into six areas, consisting of Inner Belfast, Outer Belfast, environs of Belfast, urban districts, small towns, and truly rural districts. Inner Belfast was the central part of Belfast County Borough containing approximately half of the County Borough's population: this area had already been defined in work carried out by the Department of Social and Preventive Medicine of the Queen's University of Belfast. Outer Belfast comprised the remainder of Belfast C.B. The Census Office had already coded lung cancer and bronchitis deaths by these areas. The environs of Belfast comprised Newtownabbey Urban District plus the townlands of Castlereagh, Hillsborough, and Lisburn Rural Districts. Urban districts consisted of Londonderry C.B., all Municipal Boroughs, and all urban districts except Newtownabbey U.D. Small towns consisted of 19 towns and villages containing 50 or more houses, having no legally defined boundaries, and with a population of at least 1,000. Truly rural districts were the remainder of Northern Ireland. The population in each type of area is given in Tables IV and V.

The results of the interviews were summarized by the Health Surveys Unit of AGB Research. Most of the tables in this paper were calculated by this unit and are taken from a detailed report on the results of the survey (Wicken, 1966). The comments in the present paper and the organization and planning of the study are, of course, my personal responsibility.

The lung cancer and bronchitis mortality rates among adults (male and female) aged 35 or more in Northern Ireland during the years $1960-2$ are given in Table I. 
TABLB I.-Lung Cancer and Bronchitis Mortality Rates per 100,000 per Year in Northern Ireland, 1960-2, Among Men and Women Aged $35+$

\begin{tabular}{|c|c|c|c|}
\hline & & Lung Cancer & Bronchitis \\
\hline $\begin{array}{l}\text { Males } \\
\text { Pemales : }\end{array}$ & $\begin{array}{ll} & . \\
. & . .\end{array}$ & $\begin{array}{r}100 \\
17\end{array}$ & $\begin{array}{r}144 \\
63\end{array}$ \\
\hline
\end{tabular}

Table II gives the standardized mortality ratios for lung cancer and bronchitis. In this table the number of deaths observed in Northern Ireland is expressed as a percentage of the number which would have occurred if the death rates from lung cancer and bronchitis for England and Wales at each age had applied to the population of Northern Ireland.

TABLE II.-Standardized Mortality Ratios for Lung Cancer and Bronchitis in Northern Ireland, 1960-2, Among Men and Women Aged $35+$

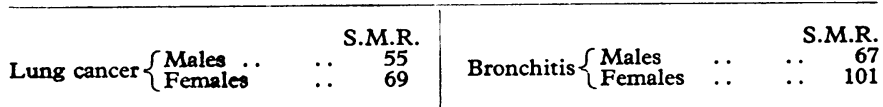

The male and female lung cancer mortality rates and the male bronchitis mortality rate in Northern Ireland were substantially below the corresponding rates for England and Wales. Rather surprisingly, however, the female bronchitis mortality rate was virtually the same as that for England and Wales. As is shown below, there is a definite association between cigarettesmoking and bronchitis mortality, and as women in England smoked cigarettes to a greater extent than did women in Northern Ireland, it might have been expected that the female bronchitis mortality rate would have been significantly lower in Northern Ireland than in England and Wales, as was found for men. If there had been some factor peculiar to the climate or air pollution of Northern Ireland that had contributed to female bronchitis mortality, the same factor might have been expected to contribute also to male bronchitis mortality. On the other hand, an occupational factor-for example, byssinosis, which leads to chronic bronchitis and emphysema-affecting women much more than men could explain the statistical evidence. Elwood et al. (1965) found "a strong association between exposure to flax dust and byssinosis" in the flax-mills of Northern Ireland and a " marked association" between byssinosis and bronchitis. More women than men aged 35 or more were employed in the flax-mills.

An objection to comparisons between the figures for Northern Ireland and the corresponding figures for England and Wales might be that the mortality rates of the two areas are not comparable, since the average standard of diagnosis in Northern Ireland, so far as lung cancer and bronchitis are concerned, may have differed from the average standard of diagnosis in England and Wales. It is, however, unlikely that there was a significant difference between the standards of diagnosis of lung cancer and bronchitis in the two countries. The National Health Service operates in both areas, and there are no parts of Northern Ireland where access to National Health Service facilities is particularly difficult.

\section{Smoking Habits}

In order to calculate lung cancer and bronchitis mortality rates it was necessary to ascertain not only the numbers who had died from these diseases in the different residential and smoking groups but also the numbers of living men and women who were non-smokers and of each type and level of smoking. Accordingly a survey of smoking habits was carried out. In each of the six areas one member of 1,500 households, which had been selected at random, was interviewed and asked about his or her smoking habits and those of other members of the household aged 35 or over. Information about the smoking habits of 12,307 people was thus obtained directly or at second hand in 8,171 interviews. Information was obtained only in broad categories-for example, whether a person smoked, and whether the number of cigarettes smoked per day was 1-10, $11-22$, or 23 or more. Ex-smokers were combined with current smokers in the tables given in this paper, except in Table IX, and the effect of this on the mortality rates is considered later. The distribution of the population between different smoking habits for the six areas was fairly consistent. The largest differences were between the figures for Inner Belfast and truly rural districts. The figures for these two areas and Northern Ireland as a whole, with comparable figures for Great Britain, are given in Table III.

TABLE III.-Smoking Habit Distribution of Men and Women Aged $35+$ TABLB III.-Smoking Habit Distribution of Men and Women Aged 35

\begin{tabular}{|c|c|c|c|c|c|c|c|c|}
\hline & \multicolumn{4}{|c|}{ Men } & \multicolumn{4}{|c|}{ Women } \\
\hline & $\begin{array}{c}\text { Inner } \\
\text { Bel- } \\
\text { fast } \\
(\%)\end{array}$ & $\begin{array}{c}\text { Truly } \\
\text { Rural } \\
\text { Dis- } \\
\text { tricts } \\
(\%)\end{array}$ & $\begin{array}{l}\text { N. } \\
\text { Ire- } \\
\text { land } \\
(\%)\end{array}$ & $\begin{array}{l}\text { G.B. } \\
(\%)\end{array}$ & $\begin{array}{c}\text { Inner } \\
\text { Bel- } \\
\text { fast } \\
(\%)\end{array}$ & \begin{tabular}{|c|} 
Truly \\
Rural \\
Dis- \\
tricts \\
$(\%)$ \\
\end{tabular} & $\begin{array}{l}\mathrm{N} . \\
\text { Ire- } \\
\text { land } \\
(\%)\end{array}$ & G.B. \\
\hline $\begin{array}{l}\text { Non-smokers } \\
\text { Smokers of: }\end{array}$ & 15 & 27 & 22 & 12 & 70 & 85 & 75 & 53 \\
\hline $\begin{array}{c}\text { Cigarettes only: } \\
1-10 \text { per day } \\
11-22 \text {, }, \\
23+\ldots\end{array}$ & $\begin{array}{l}22 \\
31 \\
16\end{array}$ & $\begin{array}{r}18 \\
22 \\
8\end{array}$ & $\begin{array}{l}21 \\
28 \\
11\end{array}$ & $\begin{array}{l}18 \\
26 \\
22\end{array}$ & $\begin{array}{r}19 \\
8 \\
3\end{array}$ & $\begin{array}{r}10 \\
4 \\
1\end{array}$ & $\begin{array}{r}16 \\
7 \\
2\end{array}$ & $\begin{array}{r}24 \\
18 \\
5\end{array}$ \\
\hline $\begin{array}{c}\text { Cigarettes and pipe/ } \\
\text { cigars }\end{array}$ & 7 & 6 & 7 & 11 & - & 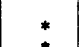 & 。 & 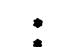 \\
\hline Pipe/cigars only .. & 10 & 20 & 12 & 11 & & * & $*$ & 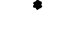 \\
\hline
\end{tabular}

From these figures and the results of interviews with relatives of lung cancer andkbronchitis subjects, it is possible to calculate lung cancer and bronchitis mortality rates. One possible qualification of these rates should be borne in mind. Todd and Laws (1959) and Todd (1966) have examined the degree of accuracy with which a smoker can be expected to report his own past smoking habits. In the present study, however, widows and other relatives were asked about the smoking habits of their husbands and other relatives who had died up to four and a half years previously. Some examinations of the accuracy of statements made by a widow about a deceased husband's smoking habits have been made by Stocks (1958), Haenszel et al. (1962), and Todd (1966). The broad conclusion from their work seems to be that statements by widows have approximately the same order of accuracy (or inaccuracy) as earlier statements by subjects themselves.

The present study may, nevertheless, be open to a special source of inaccuracy. It is conceivable that the knowledge that a husband had died of a disease that is known to be associated with smoking may have led a widow to overstate the amount that her husband had smoked. If this had happened it would not have been detected in the present study. On the other hand, since it is much less likely that such a widow would have reported her husband to have been a smoker when he had really been a non-smoker, it is reasonable to expect the total number of smokers to have been accurately reported even if the number of heavy smokers had been overstated and the number of light smokers understated. If this latter type of error did in fact happen it would mean that the mortality rates of heavy smokers given in Tables IV-VII and IX would be overstated and those for light smokers understated.

\section{Area of Residence}

The lung cancer mortality rates in the six different types of area of Northern Ireland analysed by smoking habits are given in Tables IV and V. The rates shown for each area have been standardized to the age distribution of Northern Ireland in order to eliminate variation due to differences in the age structure of the areas.

The usual feature of a lung cancer mortality rate increasing from non-smokers to heavy cigarette smokers is to be seen in Tables IV and $\mathrm{V}$ in each type of district for both men and 
women, apart from four small anomalies in the female figures possibly due to smallness of numbers. A few exceptionally high mortality rates for smokers of 23 or more cigarettes a dayfor example, 772 for men in small towns and 716 in environs of Belfast-may be due to an error of overstatement of the smoking levels of lung cancer subjects relatively to controls. Even so, the trend is clear.

In general it can also be reasonably concluded that there is a rural/urban contrast in the lung cancer mortality rates for non-smokers and for smokers of each type and level for both men and women in Northern Ireland. The rural/urban contrast in mortality rates is of course very much less than the cigarettesmoking gradient, and there are more inconsistencies in the rural/urban contrast, especially in areas of moderate urbanization. The numbers in these areas on which the rates are based were, however, relatively small, and this probably accounts for the anomalous figures.

The corresponding age-standardized bronchitis mortality rates for men in each category of smoking habits in the six areas of Northern Ireland are given in Table VI.

\section{Cigarette-smoking and Bronchitis}

An association between cigarette-smoking and bronchitis has been sufficiently established to require no further comment. The evidence is reviewed, for example, in the reports of the Royal College of Physicians (1962) and the U.S. Surgeon General's Advisory Committee (1964). Perhaps one of the main outstanding questions is whether bronchitis is more frequent among heavy than light cigarette smokers or whether bronchitis is related only to the practice of smoking cigarettes, regardless of the amount smoked. No evidence was found, in several morbidity studies, of a substantial increase in the incidence of bronchitis with the amount smoked. Ogilvie and Newell (1957) found no association between the number of cigarettes smoked, either currently or in the past, and bronchitis, "the fact of smoking cigarettes at all being the relevant factor." In several studies (Higgins, 1959 ; Higgins et al., 1959) there appeared to be an increasing incidence of the earlier symptoms of bronchitis as the amount smoked increased, but in the later stages of the disease the differences in incidence between light and heavy cigarette smokers were relatively small. Fletcher and Tinker (1961) offered two possible explanations of this phenomenon. Using a different approach, Glynn (1961) reached a slightly different conclusion: "Within the bronchitis group of biopsies the degree of mucous change was not related to the use of tobacco or the presence of infection but depended on the duration of the disease."

On the other hand, Doll and Hill (1964) found that the deathrate from both " chronic bronchitis" and "chronic bronchitis as associated cause" increased very clearly with the number

TABLE IV.-Age-standardized Lung Cancer Mortality Rates per 100,000 per Year of Men (Aged 35+) in Various Smoking-habit and Area Groups in Northern Ireland

\begin{tabular}{|c|c|c|c|c|c|c|c|}
\hline & $\begin{array}{l}\text { Inner } \\
\text { Belfast }\end{array}$ & $\begin{array}{l}\text { Outer } \\
\text { Belfast }\end{array}$ & $\begin{array}{l}\text { Urban } \\
\text { Districts }\end{array}$ & $\begin{array}{l}\text { Small } \\
\text { Towns }\end{array}$ & $\begin{array}{l}\text { Environs } \\
\text { of Belfast }\end{array}$ & $\begin{array}{c}\text { Truly Rural } \\
\text { Districts }\end{array}$ & $\begin{array}{l}\text { Northern } \\
\text { Ireland }\end{array}$ \\
\hline 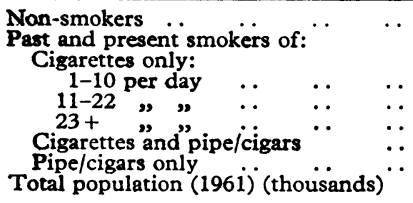 & $\begin{array}{c}36(6) \\
138(37) \\
288(90) \\
509(75) \\
124(15) \\
73(18) \\
43.7\end{array}$ & $\begin{array}{c}40(10) \\
140(25) \\
207(43) \\
430(53) \\
156(13) \\
62(11) \\
40.8\end{array}$ & $\begin{array}{c}21(7) \\
121(33) \\
171(57) \\
515(60) \\
81(10) \\
57(17) \\
59 \cdot 8\end{array}$ & $\begin{array}{c}71(3) \\
260(9) \\
772(11) \\
134(2) \\
13(1) \\
6.6\end{array}$ & $\begin{array}{c}16(1) \\
60(6) \\
192(16) \\
716(13) \\
204(6) \\
65(3) \\
19 \cdot 9\end{array}$ & $\begin{array}{r}10(9) \\
25(12) \\
74(46) \\
173(40) \\
48(11) \\
28(31) \\
121 \cdot 4\end{array}$ & $\begin{array}{c}18(33) \\
87(116) \\
168(261) \\
383(252) \\
94(57) \\
41(81) \\
292 \cdot 3\end{array}$ \\
\hline
\end{tabular}

Figures in parentheses in this and the following tables show the number of deaths on which the rates are based.

TABLE V.-Age-standardized Lung Cancer Mortality Rates per 100,000 per Year of Women (aged 35+) in Various Smoking-habit and Area Groups in Northern Ireland

\begin{tabular}{|c|c|c|c|c|c|c|c|}
\hline & $\begin{array}{c}\text { Inner } \\
\text { Belfast }\end{array}$ & $\begin{array}{l}\text { Outer } \\
\text { Belfast }\end{array}$ & $\underset{\text { Districts }}{\text { Urban }}$ & $\begin{array}{l}\text { Small } \\
\text { Towns }\end{array}$ & $\begin{array}{l}\text { Environs } \\
\text { of Belfast }\end{array}$ & $\begin{array}{l}\text { Truly Rural } \\
\text { Districts }\end{array}$ & $\begin{array}{l}\text { Northern } \\
\text { Ireland }\end{array}$ \\
\hline $\begin{array}{l}\text { Non-smokers .. .. } \\
\text { Past and present smokers of cigarettes } \\
\text { only: }\end{array}$ & $16(23)$ & $11(12)$ & $12(17)$ & $15(3)$ & $10(4)$ & $9(29)$ & $11(88)$ \\
\hline 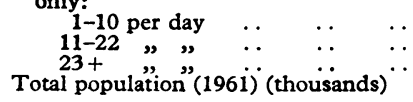 & $\begin{array}{r}33(6) \\
172(4) \\
78(5) \\
54 \cdot 8\end{array}$ & $\begin{array}{r}13(3) \\
101(6) \\
155(3) \\
52 \cdot 8\end{array}$ & $\begin{array}{r}27(5) \\
68(7) \\
615(5) \\
77 \cdot 2\end{array}$ & $\begin{array}{c}73(1) \\
73(1) \\
7 \cdot 8\end{array}$ & $\frac{50(2)}{21 \cdot 7}$ & $\begin{array}{l}11(2) \\
56(7) \\
40(5) \\
120 \cdot 7\end{array}$ & $\begin{array}{r}25(19) \\
74(25) \\
210(18) \\
334 \cdot 9\end{array}$ \\
\hline
\end{tabular}

TABLE VI.-Age-standardized Bronchitis Mortality Rates per 100,000 per Year of Men (aged 35+) in Various Smoking-habit and Area Groups in Northern Ireland

\begin{tabular}{|c|c|c|c|c|c|c|c|c|}
\hline & & $\begin{array}{c}\text { Inner } \\
\text { Belfast }\end{array}$ & $\begin{array}{l}\text { Outer } \\
\text { Belfast }\end{array}$ & $\begin{array}{c}\text { Urban } \\
\text { Districts }\end{array}$ & $\begin{array}{l}\text { Small } \\
\text { Towns }\end{array}$ & $\begin{array}{c}\text { Environs } \\
\text { of Belfast }\end{array}$ & $\begin{array}{c}\text { Truly Rural } \\
\text { Districts }\end{array}$ & $\begin{array}{c}\text { Northern } \\
\text { Ireland }\end{array}$ \\
\hline $\begin{array}{l}\text { Non-smokers .. } \\
\text { Past and present smokers of: } \\
\text { Cigarettes only: } \\
1-10 \text { per day } \quad \ldots \\
11-22 \text { " " } \quad \ldots \\
23+\quad \text { " } \\
\text { Cigarettes and"pipe/cigars } \\
\text { Pipe/cigars only } \quad . .\end{array}$ & $\begin{array}{l}\cdots \\
\because \\
\because \\
\end{array}$ & $\begin{array}{l}216(38) \\
411(107) \\
327(100) \\
475(68) \\
158(20) \\
339(80)\end{array}$ & $\begin{array}{l}81(20) \\
315(56) \\
333(63) \\
222(28) \\
128(11) \\
186(40)\end{array}$ & $\begin{array}{l}44(16) \\
152(41) \\
242(62) \\
366(37) \\
103(12) \\
148(47)\end{array}$ & $\begin{array}{l}- \\
363 \overline{(11)} \\
161 \overline{(2)} \\
126(7)\end{array}$ & $\begin{array}{l}68(5) \\
191(13) \\
277(16) \\
554(5) \\
110(7)\end{array}$ & $\begin{array}{l}42(45) \\
63(28) \\
93(48) \\
166(28) \\
76(19) \\
67(108)\end{array}$ & $\begin{array}{l}64(124) \\
189(245) \\
220(300) \\
284(168) \\
99(62) \\
118(289)\end{array}$ \\
\hline
\end{tabular}

TABLE VII.-Age-standardized Bronchitis Mortality Rates per 100,000 per Year of Women (aged 35+) in Various Smoking-habit and Area Groups in Northern Ireland

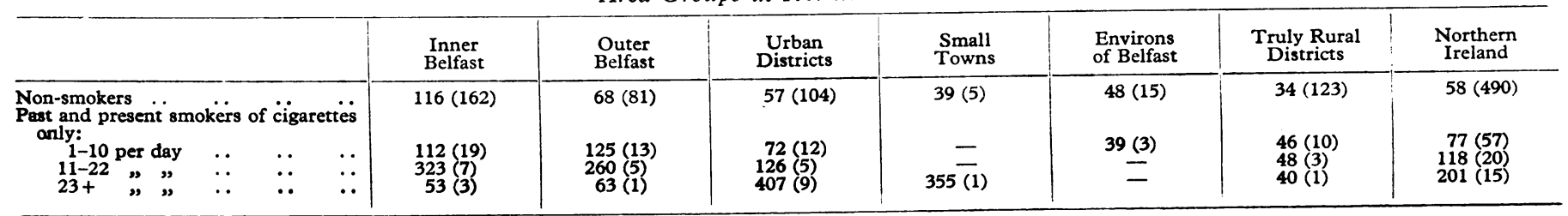


of cigarettes smoked. Wicken and Buck (1964) found the same trend in bronchitis mortality in Eston U.D., to a less extent in Stockton M.B., but not in four rural districts. In the Northern Ireland study (Table VI) there was an increasing mortality rate from bronchitis as the number of cigarettes smoked increased in urban districts, environs of Belfast, and truly rural districts, but not in Belfast itself. It is possible that in cities the contribution to bronchitis of factors related to urbanization can mask the contribution of differences in the levels of cigarette smoking.

In the Northern Ireland study non-smokers in Inner Belfast had a higher bronchitis mortality rate than cigarette smokers in truly rural districts, but it would be unwise to deduce too much from this. Table VII shows the age-standardized bronchitis mortality rates for women.

\section{Lung Cancer and Bronchitis in Non-smokers and Ex-smokers}

One of the questions it was possible to answer from the results of the Northern Ireland inquiry was, "Taking nonsmokers only, how do their mortality rates from lung cancer and bronchitis, respectively, vary from rural to urban districts?" The relevant figures are given in Table VIII. As will be seen, lung cancer and bronchitis mortality rates for non-smoking men were three to four times as high in Belfast as in rural areas. The picture, however, is not one of complete consistency. Some of the figures for areas of intermediate urbanization do not fall exactly into place. But these are also areas of very small numbers, and this may account for the inconsistencies. Apart from these figures, there is clearly, even among non-smokers, a rural/urban contrast in both lung cancer and bronchitis mortality rates of men and women in Northern Ireland.

TABLE VIII.-Age-standardized Lung Cancer and Bronchitis Mortality Rates per 100,000 per Year Among Non-smokers (Aged 35 + ) in Northern Ireland 1960-2

\begin{tabular}{|c|c|c|c|c|c|}
\hline & & \multicolumn{2}{|c|}{ Lung Cancer } & \multicolumn{2}{|c|}{ Bronchitis } \\
\hline & & Males & Females & Males & Females \\
\hline 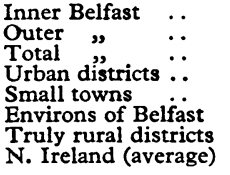 & $\begin{array}{l}\because \\
\because \\
\because \\
\because \\
\cdots \\
\cdots\end{array}$ & $\begin{array}{l}36(6) \\
40(10) \\
38(16) \\
21(7) \\
16(1) \\
10(9) \\
18(33)\end{array}$ & $\begin{array}{l}16(23) \\
11(12) \\
14(35) \\
12(17) \\
15(3) \\
10(4) \\
9(29) \\
11(88)\end{array}$ & $\begin{array}{c}216(38) \\
81(20) \\
137(58) \\
44(16) \\
68(5) \\
42(45) \\
64(124)\end{array}$ & $\begin{array}{l}116(162) \\
68(81) \\
94(243) \\
57(104) \\
39(5) \\
48(15) \\
34(123) \\
58(490)\end{array}$ \\
\hline
\end{tabular}

In Tables III-VIII ex-smokers were classified according to their former smoking habits, so that non-smokers were those reported as never having been smokers. In Table IX the lung cancer and bronchitis mortality rates for men aged 35 and over in Northern Ireland are analysed separately for those who had given up smoking some time before their final illness and those who had continued to smoke up until the time of their death.

TABLE IX.-Age-standardized Lung Cancer and Bronchitis Mortality Rates per 100,000 per Year Among Ex-smokers and Continuing Smokers (Aged 35+) in Northern Ireland, 1960-2

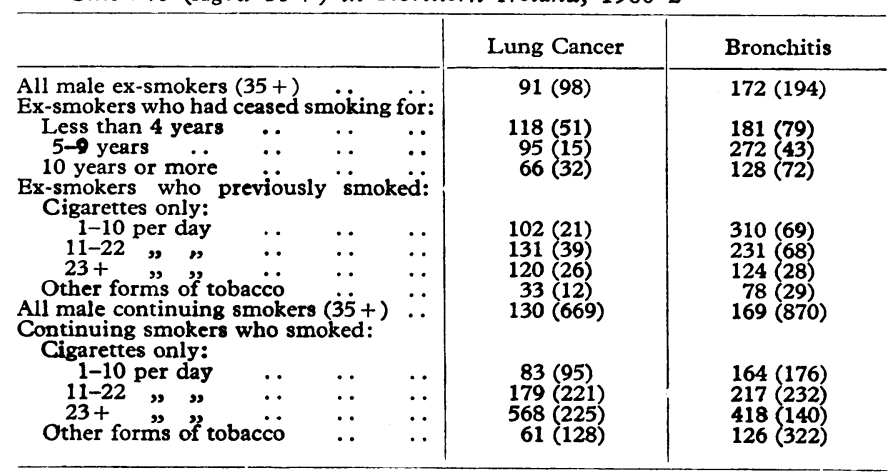

The lung cancer mortality rate among ex-smokers declined with the passage of time after smoking ceased and was slightly greater among those who had previously been relatively heavy smokers of cigarettes only. The death rate from bronchitis did not decline consistently with the passage of time after smoking ceased, and was apparently inversely related to the number of cigarettes previously smoked. This latter trend is unexpected in view of the positive association, among continuing smokers and the combination of both continuing and ex-smokers, between the bronchitis mortality rate and the number of cigarettes smoked. It might be explained, however, on the hypothesis that some heavy smokers with chronic bronchitis first reduced their consumption of cigarettes and only later ceased smoking, with the result that, after their death, they were classified as light smokers. The inclusion of ex-smokers in Tables IV and VI has had the effect of reducing the overall male mortality rates from lung cancer and bronchitis in Northern Ireland for only the highest levels of cigarette smoking. Thus if exsmokers had not been included in these tables the lung cancer mortality rate for men smoking 23 or more cigarettes a day in Northern Ireland would have been 568 per 100,000 per year instead of 383 per 100,000 per year (Table IV), and the corresponding figure for bronchitis mortality would have been 418 instead of 284 (Table VI).

\section{Non-smokers in Rural Areas}

One of the important questions that have been asked in relation to mortality from lung cancer and bronchitis is: "What is the death rate from lung cancer and bronchitis in the absence of both smoking and urbanization ?" Table X summarizes the estimates of the lung cancer and bronchitis mortality rates of non-smokers in rural areas that are available from inquiries carried out in the United Kingdom.

TABLE X.-Lung Cancer and Bronchitis Mortality Rates of Non-smokers per 100,000 per Year Estimated in U.K. Inquiries

\begin{tabular}{|c|c|c|}
\hline Area Covered, etc. & Lung Cancer & Bronchitis \\
\hline 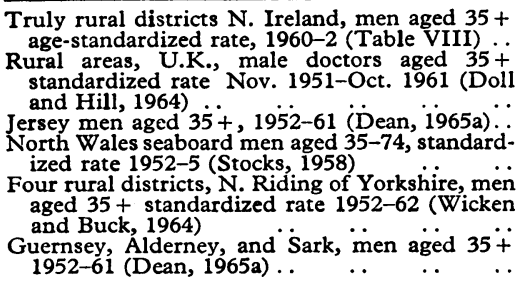 & $\begin{array}{l}10(9) \\
12(1) \\
18(2) \\
22(5) \\
29(5) \\
33(4)\end{array}$ & $42(45)$ \\
\hline
\end{tabular}

The figures in Table $\mathrm{X}$ have almost certainly been standardized on different bases, and for other reasons the figures are not strictly comparable. Further, although the Channel Islands are not industrialized, it may not be wholly accurate to regard them as rural areas. Even with these limitations on comparability, the figures in Table $\mathrm{X}$ show more variation than might have been expected, possibly as a result of the smallness of the numbers on which the rates are based. According to the present study, however, the lung cancer mortality rate for non-smokers in truly rural districts of Northern Ireland was 10 deaths per 100,000 per year for men and 9 deaths per 100,000 per year for women. The corresponding mortality rates for bronchitis were 42 for men and 34 for women.

It is of particular interest that the lung cancer mortality rate for male non-smokers in the truly rural districts of Northern Ireland-that is, in the presumed absence of all air pollutionshould be as low as 10 deaths per 100,000 per year. In a study of lung cancer in South Africa (Dean, 1961) the lowest lung cancer death-rate encountered was the rate for male nonsmokers aged 45-64 who had been born in South Africa, who lived in rural districts, and who were non-smokers. Their lung cancer mortality rate was 8 deaths per 100,000 per year. 
However, the age groups covered by the South African studynamely, 45-64-differed from those covered in the Northern Ireland study $(35+)$; but, putting the present study on the same basis, there were only four male non-smokers aged 45-64 who lived in the truly rural districts of Northern Ireland and who died of lung cancer in the period 1960-2. This number of deaths is equivalent to a rate of 9 per 100,000 per year for men aged 45-64. The lung cancer mortality rate of male nonsmokers in truly rural districts of Northern Ireland was therefore practically the same as the South African figure for locally born men, despite the great differences between the climates of the two areas. The Northern Ireland rate was also not very different from the rate of 14 found by Mills (1960) for male non-smokers aged 40-69 in rural Ohio in 1947-55.

If the male lung cancer mortality rate in the United Kingdom may be taken, in the absence of smoking and air pollution and other contributions by urbanization, as being about 10 deaths per 100,000 per year, then the higher mortality rates than this found for rural non-smokers in other surveys quoted in Table $\mathrm{X}$ suggest that air pollution may have had a more widespread effect, or that urban dwellers had moved to rural areas to a greater extent, than had been previously appreciated, even though the smallness of the numbers involved may also have contributed to some of the unexpectedly high figures.

It has been argued-for example, Doll (1953, 1963)-that, in the absence of smoking, an urban factor makes little or no significant contribution to lung cancer. Sufficient figures are now available for non-smokers to show that both the lung cancer and bronchitis mortality rates of non-smokers are significantly higher in urban than in rural areas.

\section{Social Class}

In the Northern Ireland inquiry the possible association of lung cancer mortality and bronchitis mortality with four other factors was examined. These factors were social class (as represented by occupation), other chest illnesses, morning cough three years or more prior to death, and frequency among rela-

TABLE XI.-Lung Cancer and Bronchitis Mortality Rates per 100,000 per Year Among Men (Aged $35+$ ) in Various Social Class Groups in Northern Ireland, 1960--2

\begin{tabular}{ll|c|c}
\multicolumn{1}{c|}{ Social Class } & Lung Cancer & Bronchitis \\
\hline Professional and intermediate occupations & $\ldots$ & $75(144)$ & $98(221)$ \\
Skilled occupations & $\ldots$ & $121(362)$ & $154(434)$ \\
Partly skilled and unskilled occupations.. & $\ldots$ & $114(285)$ & $199(534)$
\end{tabular}

tives of deaths from cancer or bronchitis. The association of male lung cancer and bronchitis mortality rates with social class is shown in Table XI.

There are significant social class differences in the incidence of both lung cancer and bronchitis in men. A social class gradient in male lung cancer mortality rates in all or parts of England and Wales has also been found by the RegistrarGeneral of England and Wales (1958) and by Wicken and Buck (1964). A social class gradient in mortality or morbidity from bronchitis in the U.K. has been found by Edwards et al. (1959), the Registrar-General (1958), the College of General Practitioners (1961), Buck and Brown (1964), and Wicken and Buck (1964). None of these figures was standardized for differences between social classes in smoking habits, but the absence of this standardization is unlikely to have affected the conclusions reached. Todd (private communication) has stated that the higher lung cancer mortality rates in the lower social classes "can hardly be attributed to differences in smoking habits." He added that the contrast between the cigarette consumption per head and lung cancer mortality of the different social classes was accentuated "if smoke intake per puff is considered, rather than just the number of cigarettes smoked, since the cigarettes smoked by the professional classes, on account of the greater cross-section of these cigarettes, yield about $20 \%$ more smoke per puff than those smoked frequently by the unskilled classes."

\section{Previous Chest Illness}

It is natural to suspect that there may have been difficulties in obtaining information about past chest illnesses on a comparable basis in respect of people who died from a chest disease and those who died from other causes. Widows or relatives of the former may be more likely to be "chest-disease conscious." In view of this possibility the differences in the incidence of other chest illnesses between subjects and controls shown in Table XII would seem to be relatively minor. TABLE XII.-Incidence of Other Chest Illnesses Among Lung Cancer and
Bronchitis Subjects and Controls in Northern Ireland

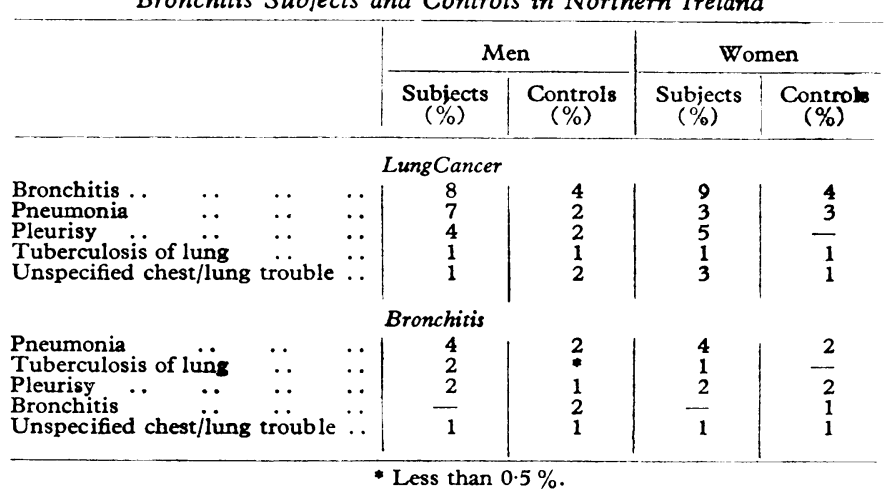

\section{Morning Cough}

Table XIII shows that, by the lung cancer and bronchitis ages (if the population represented by the controls may be so described), about one-third of the men and one-sixth of the women in Northern Ireland had had a morning cough three years or more before death. But it is among those with a morning cough that those who die of lung cancer or bronchitis are particularly to be found. As Table XIII also shows, $68 \%$ of the men who died from lung cancer and $77 \%$ of those who died from chronic bronchitis had had a morning cough three years or more before death. Moreover, the lung cancer subjects included a higher percentage with morning cough three years or more before death than the controls at all levels of smoking, and even among the non-smokers, in both sexes. The figures are shown in Table XIV.

It might be argued that most lung cancer and bronchitis subjects probably had a morning cough at death, and that many

TABLE XIII.-Morning Cough Three Years or More Before Death in Relation to Lung Cancer and Bronchitis in Northern Ireland

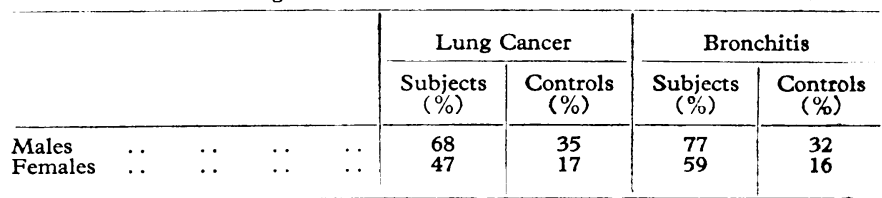

TABLE XIV.-Incidence of Morning Cough Three Years or More Before Death Among Lung Cancer Subjects and Controls in Northern Ireland Analysed by Smoking Habits

\begin{tabular}{|c|c|c|c|c|}
\hline & \multicolumn{2}{|c|}{ Male Lung Cancer } & \multicolumn{2}{|c|}{ Female Lung Cancer } \\
\hline & $\begin{array}{c}\text { Subjects } \\
(\%)\end{array}$ & $\begin{array}{c}\text { Controls } \\
(\%)\end{array}$ & $\begin{array}{c}\text { Subjects } \\
(\%)\end{array}$ & $\begin{array}{c}\text { Controls } \\
(\%)\end{array}$ \\
\hline $\begin{array}{l}\text { Non-smokers } \ldots \\
\text { Smokers of cigarettes only: }\end{array}$ & 21 & 15 & 35 & 13 \\
\hline 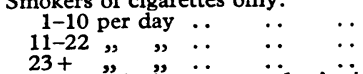 & $\begin{array}{l}60 \\
72 \\
83\end{array}$ & $\begin{array}{l}25 \\
49 \\
63\end{array}$ & $\begin{array}{l}58 \\
64 \\
67\end{array}$ & $\begin{array}{l}36 \\
27 \\
40\end{array}$ \\
\hline $\begin{array}{l}\text { Smokers "of cigarettes and pipel } \\
\text { cigars } \\
\text { Smokers of pipe/cigars only } \quad .\end{array}$ & $\begin{array}{l}67 \\
46\end{array}$ & $\begin{array}{l}42 \\
19\end{array}$ & 二 & - \\
\hline
\end{tabular}


widows might have erroneously extended the duration of the cough back for three years when asked about it at the interview. But this interpretation of the data seems rather unlikely for the following reasons:

(a) It is improbable that those interviewed would have misunderstood the question about cough.

(b) Table XIII shows that many relatives, even of the bronchitis subjects, all or most of whom were likely to have had a cough of long duration up to the time of their death, did not report that the subject had had a morning cough three or more years previously. This suggests in fact a tendency to under-report rather than over-report the existence of a prolonged morning cough prior to death.

(c) The proportions of lung cancer subjects who had a morning cough (Table XIV) showed a consistent increase with the amount smoked. The figures would perhaps have been less likely to show this if they had been subject to random errors arising from the personality characteristics of the person interviewed.

The figures in Table $\mathrm{XV}$ give the lung cancer mortality rates per 100,000 per year for those who three years before death were non-coughers and morning coughers, respectively, for men and women.

TABLE XV.-Age-standardized Lung Cancer Mortality Rates per 100,000 per Year of Men and Women Aged 35 + in Northern Ireland, 1960-2

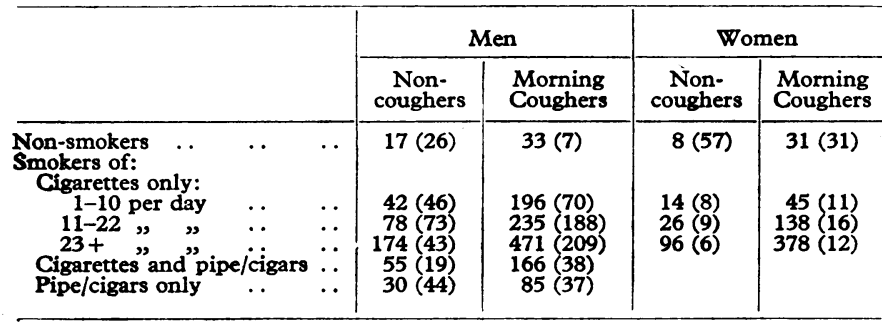

The figures in Table XV suggest that men and women in Northern Ireland who have had a morning cough for at least three years have two to five times the lung cancer mortality rates of non-coughers. This is in approximate agreement with two sets of figures from the U.S.A. In the Philadelphia Pulmonary Neoplasm Research Project (Boucot et al., 1961, 1966) it was found that the percentage who developed proved primary lung cancer was twice as great among smokers who had had a "cough for months or years" as among non-coughing smokers, and the difference between the two groups was statistically significant. The lung cancer rates were also persistently higher in coughing than in non-coughing cigarette smokers at each level of smoking (but not among non-smokers), but the numbers in each smoking category were not sufficient to reach statistical significance. Hammond (1964) found that the lung cancer rate among men who had had a cough was 3.44 times the rate among non-coughers. As is suggested later, the high percentage of cigarette smokers among lung cancer subjects who had had a morning cough for three years or more prior to death indicates that cigarette smokers with persistent morning cough are in a particularly high lung cancer risk group.

\section{Family Incidence of Mortality}

Table XVI shows the incidence of mortality from cancer and bronchitis reported by relatives of lung cancer and bronchitis subjects and controls in Northern Ireland.

In papers by Tokuhata and Lilienfeld (1963) and by Tokuhata (1964) it was concluded that lung cancer occurred significantly more frequently among the families of lung cancer subjects than among the families of others. Tokuhata and Lilienfeld further concluded that "our findings indicate the existence of familial aggregation of lung cancer after cigarette smoking is taken into account." The smoking habits of relatives were not ascertained in the Northern Ireland inquiry, so that the figures cannot be standardized for differences in smoking habits. There was an excess of lung cancer among the relatives of subjects compared with controls in Northern Ireland, as shown in Table XVI. Such significant differences as existed could have been due to a predisposition in the family either to suffer from cancer or chest illnesses or to be exposed to similar smoking habits or residence as the subjects of the present investigation. Alternatively, it is possible that the differences could have been due to the greater interest of widows of men who died of a particular disease in the occurrence of the disease in their families, making them more likely to report such cases at the interview.

TABLE XVI.-Mortality from Cancer and Bronchitis Among Relatives of Lung Cancer and Bronchitis Subjects and Controls in Northern Ireland

\begin{tabular}{|c|c|c|c|c|c|}
\hline & & \multicolumn{2}{|c|}{ Men } & \multicolumn{2}{|c|}{ Women } \\
\hline & & $\begin{array}{c}\text { Subjects } \\
(\%)\end{array}$ & $\begin{array}{c}\text { Controls } \\
(\%)\end{array}$ & $\begin{array}{c}\text { Subjects } \\
(\%)\end{array}$ & $\begin{array}{c}\text { Controls } \\
(\%)\end{array}$ \\
\hline \multicolumn{6}{|c|}{ Lung Cancer } \\
\hline $\begin{array}{l}\text { Lung cancer } \\
\text { Other or unspecified cancer } \\
\text { Bronchitis .. }\end{array}$ & $\because:$ & $\begin{array}{r}4 \\
22 \\
6\end{array}$ & $\begin{array}{r}1 \\
17 \\
3\end{array}$ & $\begin{array}{r}4 \\
21 \\
4\end{array}$ & $\begin{array}{r}2 \\
15 \\
3\end{array}$ \\
\hline \multicolumn{6}{|c|}{ Bronchitis } \\
\hline 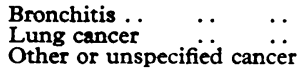 & $\begin{array}{l}. \\
\because .\end{array}$ & $\begin{array}{r}13 \\
1 \\
8\end{array}$ & $\begin{array}{r}5 \\
1 \\
11\end{array}$ & $\begin{array}{r}14 \\
1 \\
9\end{array}$ & $\begin{array}{r}6 \\
1 \\
10\end{array}$ \\
\hline
\end{tabular}

\section{Month of Birth}

Dr. B. K. S. Dijkstra (1963), of Groningen, has claimed to have found an association between lung cancer and the month of birth. He found that an excess of lung cancer patients were born in the month of March, and outlined a theory that might account for this peculiar characteristic. Both lung cancer and bronchitis subjects in the present study were analysed according to month of birth, but no association was discovered between month of birth and either cause of death.

\section{Acute and Chronic Bronchitis}

Mortality from acute bronchitis in Northern Ireland provides some contrasts with mortality from chronic bronchitis. Table XVII illustrates some of the differences between acute and chronic bronchitis in respect of associated characteristics.

TABLE XVII.-Smoking Habits and Social Class of Subjects Dying of Acute and Chronic Bronchitis in Northern Ireland

\begin{tabular}{|c|c|c|c|c|c|}
\hline & & \multicolumn{2}{|c|}{ Male Subjects } & \multicolumn{2}{|c|}{ Female Subjects } \\
\hline & & $\begin{array}{c}\text { Acute } \\
\text { Bronchitis } \\
(\%)\end{array}$ & $\begin{array}{c}\text { Chronic } \\
\text { Bronchitis } \\
(\%)\end{array}$ & $\begin{array}{c}\text { Acute } \\
\text { Bronchitis } \\
(\%)\end{array}$ & $\begin{array}{c}\text { Chronic } \\
\text { Bronchitis } \\
(\%)\end{array}$ \\
\hline $\begin{array}{lll}\text { Non-smokers } & \ldots & \ldots \\
\text { Smokers } \ldots & \ldots & \ldots \\
\text { Social class: } & \ldots \\
\text { Professional or intermediate } \\
\text { Skilled } \\
\text { Partly skilled or unskilled } \\
\text { Unclassified } \quad \ldots & . .\end{array}$ & $\begin{array}{l}\cdots \\
\cdots \\
\cdots \\
\cdots\end{array}$ & $\begin{array}{r}23 \\
77 \\
31 \\
29 \\
32 \\
8\end{array}$ & $\begin{array}{r}10 \\
90 \\
17 \\
36 \\
42 \\
5\end{array}$ & $\begin{array}{r}91 \\
9\end{array}$ & $\begin{array}{l}82 \\
18\end{array}$ \\
\hline
\end{tabular}

Subjects who died of acute bronchitis thus tended on the average to be smokers less frequently and to be of higher social class than chronic bronchitis subjects, and in fact they were roughly proportionate to the populations at risk in these respects.

One further point which was investigated in the Northern Ireland study was the extent to which bronchitis was mentioned on the death certificates during $1960-2$ as a significant condition contributing to the death. Table XVIII compares by area the mortality rates for adults aged 35 and over in Northern Ireland who died from bronchitis, where bronchitis was mentioned as the primary cause of death on the death certificate (1,892 male and female deaths), with the mortality 
rates for those who died from other causes of death to which bronchitis was a contributory cause (1,238 male and female deaths). Table XVIII.-Bronchitis Mortality Rates for 100,000 per Year for
Adults Aged $35+$ in Northern Irsland, $1960-2$

\begin{tabular}{|c|c|c|c|c|c|}
\hline & & \multicolumn{2}{|c|}{ Bronchitis } & \multicolumn{2}{|c|}{$\begin{array}{l}\text { Causes to which Bronchitis } \\
\text { was Contributory }\end{array}$} \\
\hline & & Male & Female & Male & Female \\
\hline $\begin{array}{l}\text { Inner Belfast } \ldots \\
\text { Outer d" } \ldots \\
\text { Urban districts } \\
\text { Small towns } \\
\text { Environs of Belfast } \\
\text { Truly rural districts }\end{array}$ & $\begin{array}{l}\ldots \\
\ddot{0} \\
\ddot{0}\end{array}$ & $\begin{array}{l}333(436) \\
187(229) \\
130(234) \\
106(21) \\
85(51) \\
80(291)\end{array}$ & $\begin{array}{l}124(203) \\
70(110) \\
62(144) \\
38(9) \\
31(20) \\
40(144)\end{array}$ & $\begin{array}{l}175(230) \\
110(135) \\
94(169) \\
56(11) \\
45(27) \\
62(227)\end{array}$ & $\begin{array}{l}83(136) \\
45(72) \\
42(98) \\
17(4) \\
31(20) \\
29(105)\end{array}$ \\
\hline N. Ireland & $\ldots$ & $144(1,262)$ & $62(630)$ & 91 (799) & $43(435)$ \\
\hline
\end{tabular}

The mortality rates for bronchitis as a contributory cause of death followed closely the geographical distribution of the primary bronchitis rates, ranging from a relatively high rate in Inner Belfast to a relatively low rate in the rural districts.

Primary bronchitis was the cause of almost twice as many deaths as lung cancer. In addition, bronchitis further contributed as a secondary cause to about two-thirds as many deaths as those of which it was the primary cause. Even in Northern Ireland, which has less of the health consequences of urbanization than England, bronchitis has thus directly and indirectly contributed to an important number of deaths.

\section{Statistical Conclusions and their Implications}

The conclusions to be drawn directly from the results of this inquiry are inevitably concerned mainly with statistical associations. But these statistical conclusions are relevant to preventive medicine. The main statistical conclusions that emerged from this inquiry were the following:

1. The male and female lung cancer mortality rates and the male bronchitis mortality rate, but not the female bronchitis mortality rate, in Northern Ireland were substantially below the corresponding rates for England and Wales.

2. The range of variation between the lowest and the highest lung cancer mortality rates found in the various subgroups of the adult population of Northern Ireland indicated that lung cancer mortality among both men and women during the years 1960-2 was more strongly associated with smoking than with any other environmental factor examined.

3. Bronchitis mortality in Northern Ireland among both men and women during the years $1960-2$ was associated mainly with urbanization and smoking habits.

4. Among male non-smokers lung cancer and bronchitis mortality rates in Northern Ireland were three to four times as high in Belfast as in truly rural districts, but the trend was not completely consistent for intermediate levels of urbanization, possibly owing to the smallness of the numbers.

5. The lung cancer mortality rates of male non-smokers aged 4564 in truly rural districts of Northern Ireland were about the same as those for South Africa, despite the differences in climate between the two countries.

6. Both the lung cancer and the bronchitis mortality rates of men in Northern Ireland were inversely associated with social class, but the association was much greater for bronchitis than for lung cancer.

7. Morning cough at least three years before death was much more common in lung cancer subjects of both sexes than in the controls, and the percentages in both groups having cough increased with the number of cigarettes smoked per day.

8. No association was found between month of birth and mortality from lung cancer or bronchitis.

9. The association of male bronchitis mortality with smoking habits and social class was confined to the chronic form of bronchitis. Deaths from acute bronchitis were not associated with these factors.

10. Bronchitis was the cause of almost twice as many deaths in Northern Ireland as lung cancer, and, in addition, bronchitis as a secondary cause of death further contributed to about two-thirds as many deaths as those of which it was a primary cause. Bronchitis as a contributory cause of death was also associated with urbanization in Northern Ireland.

11. The group of men characterized by heavy cigarette smoking, chronic morning cough, residence in Belfast, and partly skilled or unskilled occupation had the highest mortality rates for both lung cancer and bronchitis.

These statistical conclusions follow fairly directly and objectively from the figures emerging from the study. Subjective factors were involved in the main only in assessing the probabilities of possible errors or biases. But, in considering whether the statistical associations reflect cause-and-effect relationships or can be used in preventive medicine, personal characteristics can unconsciously give different weight to different parts of the evidence. Sir Austin Bradford Hill (1965) rightly suspected that deductions about causation from the evidence relating to an observed association "must turn upon personalities." I have assessed the evidence with, like many others, a profound concern for human health and well-being, and this concern has inevitably affected the deductions made.

\section{Deductions from the Inquiry}

The deductions made from the four main statistical associations found in the inquiry are the following:

1. My personal conclusion is that the association between smoking and lung cancer is causal in nature. This view has been recently expressed (Dean, 1964, 1965a). The criticisms of the evidence linking smoking with disease, submitted to the U.S. Senate Committee on Commerce (1965) and the U.S. Committee on Interstate and Foreign Commerce of the House of Representatives (1965), have not led me to modify my previous conclusion. The results of the present study are entirely consistent with this conclusion.

2. The causal nature of the association between smoking and bronchitis is indicated by the fact that if smoking is given up while the disease is in its early stages the course of the disease is often reversed (Fletcher, 1962; Royal College of Physicians, 1962; Mitchell et al., 1964).

3. It is more difficult to conclude that the association between urbanization and lung cancer is causal in nature. Theoretically, the association could be due wholly or in part to differences in standards of diagnosis in town and country or to the possibility that the types of persons who live in cities are genetically more prone to lung cancer than those who live in rural areas. Several arguments have been advanced-for example, by Brownlee (1965) - to suggest that it has not been proved that the association between smoking and lung cancer is causal in nature, which, with appropriate changes, could be applied to the association between urbanization and lung cancer. On the other hand, I have been impressed by the evidence that British-born immigrants to New Zealand (Eastcott, 1956, 1960), South Africa (Dean, 1959, 1961), Australia (Dean, 1962), U.S.A. (Haenszel, 1961), and even the Channel Islands (Dean, 1965a) all carry with them a greater liability to lung cancer than locally born men with the same smoking levels. It is difficult to avoid the conclusion that exposure to British urbanization and to the earlier effects of smoking habits in conjunction with the British climate have contributed to this invisible export from Britain. In the light of all the evidence it seems reasonable to conclude that the association between urbanization and lung cancer does reflect, at least in part, a cause-and-effect relationship.

4. The association between urbanization and bronchitis is well established. It has been found among male and female non-smokers to a greater extent than the association between urbanization and lung cancer. The relative absence of bronchitis among heavy smokers in South Africa, which I have observed (Dean, 1965b), indicates that other major factors than smoking must contribute to the disease. Comparative studies of the prevalence of respiratory disease-for example, Holland et al. (1965) and Reid et al. (1964)-have clearly demonstrated that an excess in the incidence of bronchitis in the United Kingdom compared with that in the United States occurred at each level of smoking and among non-smokers. Reid et al. suggested as a result of his conclusions that "some factor in British urban life, such as air pollution, was accentuating the effect of smoking on respiratory malfunction." There seems little doubt, 
therefore, that the association of bronchitis with urbanization is causal in nature.

It is not possible to state with certainty what factors related to urbanization are reflected in the associations with urbanization. Fairbairn and Reid (1958) considered three possible factors ; frequency of fog, number of persons per acre, and the percentage of persons living more than two to a room, and found that bronchitis mortality was highly associated with the fog index, whereas lung cancer mortality was more strongly associated with population density. Wicken and Buck (1964), like Reid et al. (1964), have suggested that the relevant factor is air pollution, and it is the most common suggestion. Lawther (1961) has commented that the work of Reid and Fairbairn (1958) has shown "that air pollution is probably the most serious factor in the aetiology of chronic bronchitis." Nevertheless, the evidence against atmospheric pollution is far from conclusive. If the associations of urbanization with lung cancer and bronchitis mortality are both due to air pollution then the forms or constituents of air pollution that contribute to bronchitis may not be the same as those that contribute to lung cancer.

\section{Conclusion}

These conclusions naturally lead to the further conclusions that reasons of cost ought not to be allowed to stand in the way of eliminating air pollution, and that every effort ought to be made to identify those who are liable to develop lung cancer or bronchitis or any other disease associated with smoking and to persuade these people in particular to give up or not to start smoking. Perhaps the most immediately important conclusion for preventive medicine of the present study, therefore, is that a smoker with persistent morning cough is in a group with a considerably higher risk for both lung cancer and bronchitis than a person with the same smoking habits and no cough.

Wynder et al. (1965) published a paper on the epidemiology of persistent cough, and Wynder and Fairchild (private communication) have in progress a retrospective epidemiological study of persistent cough in relation to lung cancer. On the basis of their results to date, Wynder and Fairchild found no difference in the incidence of cough between lung cancer and control patients among smokers of 30 or more cigarettes a day. Wynder and Fairchild found an association between cough and lung cancer among individuals smoking between 20 and 29 cigarettes a day, but they noticed that the lung cancer group tended to have smoked longer, to have smoked their cigarettes to a shorter butt, and, within this smoking category, to have smoked more cigarettes than the control group. Their provisional conclusion, therefore, was that cough and lung cancer were both due to smoking but that the cough did not contribute to lung cancer. This is somewhat contrary to, for example, Passey's (1962) view that lung cancer is the result of changed conditions in a respiratory system which has been damaged by chronic cough, other abnormalities, and especially bronchitis. It is necessary, however, to distinguish the types of cough involved. The study by Wynder and Fairchild was restricted to "persistent cough," which others have defined as "simple chronic bronchitis," and which is frequently reversible on ceasing smoking.

But the precise relationship between cough and lung cancer is not the point at issue here. It would be an important step forward in preventive medicine, as Doll (1965) and Kissen (1965) have indicated, if those smokers likely at some future date to develop lung cancer, bronchitis, or some other disease associated with smoking could be identified in advance and individually warned by their own physicians of the risk they are running in their present way of life. This is still very desirable even if the success rate in securing modification of the patient's way of life is likely, initially at any rate, to be small. But those who are in the high-risk groups would have to be identified on the basis of characteristics that can be ascertained without too great difficulty. These characteristics fall into two classes-those which actually contribute to the disease and those which are statistically associated with the disease but do not contribute to it. Chronic morning cough would appear, from the results of this and other studies, to be one of the most readily ascertainable characteristics that can be used to assist in identifying those who are in the groups which have relatively high risk of future lung cancer and future bronchitis-if indeed they do not already have bronchitis. Further, in view of the possibility that the onset of the disease may precede and contribute to the development of the cough, the groups at risk who have a cough must be identified and given advice at the earliest opportunity.

Many people helped to make this investigation possible, and I wish to express my appreciation of the assistance given in particular by the Chief and Deputy Chief Medical Officers of Health, the County and County Borough Medical Officers of Health, and the Registrar-General of Northern Ireland and his colleagues, and the staff of the Census Office. I have also referred above to the assistance given by the Health Surveys Unit of A.G.B. Research Ltd., which undertook the field work and tabulations. Professor $\mathrm{J}$. Pemberton kindly allowed me to make use of figures relating to Inner and Outer Belfast prepared by or for the Department of Social and Preventive Medicine in the Queen's University of Belfast. I also wish to thank the Tobacco Research Council for meeting the costs of the investigation.

\section{REFERENCES}

Boucot, K. R., Cooper, D. A., and Weiss, W. (1961). Ann. intern. Med., $54,363$.

Cooper, D. A., Weiss, W., and Carnahan, W. J. (1966). In press. Brownlee, K. A. (1965). I. Amer. statist. Ass., 60, 722.

Buck, S. F., and Brown, D. A. (1964). Mortality from Lung Cancer and Bronchitis in Relation to Smoke and Sulphur Dioxide Concentration Population Densily, and Social Index. Tobacco Research Council Research Paper No. 7. London.

College of General Practitioners (1961). Brit. med. f., 2, 973.

Dean, G. (1959). Ibid., 2, 852. (1961). Ibid., 2, 1599.

(1962). Med. F. Aust., 1, 1003

(1964). Proc. roy. Soc. Med., 57, 984

(1965a). Brit. 7. Cancer, 19, 661 .

Dijkstra, B. K. S. Afr. med. F., 31 July, Supplement.

Doll, R. (1953). Brit. F. Cancer, 7, 310.

(1963). Meth. Inform. Med.,

(1965). Brit. med. 7., 1, 471 .

and Hill, A. B. (1964). Ibid., 1, 1399, 1460

Eastcott, D. F. (1956). Lancet, 1,

Edwards, F., McKeown, T., and Whitfield, A. G. W. (1959). Lancet, 1, 196. Elwood, P. C., Pemberton, J., Merrett, J. D., Carey, G. C. R., and

Fairbairn, A. S., and Reid, D. D. (1958). Brit. F. prev. soc. Med., 12, 94.

Fletcher, C. M. (1962). Practitioner, 188, 403.

- and Tinker, C. M. (1961). Brit. med. f., 1, 1491.

Glynn, A. A. (1961). Ibid., 1, 127.

Haenszel, W. (1961). F. nat. Cancer Inst., 26, 37.

Loveland, D. B., and Sirken, M. G. (1962). Ibid., 28, 947.

Hammond, E. C. (1964). Amer. F. publ. Hlth, 54, 11.

Higgins, I. T. T. (1959). Brit. med. f., 1, 325.

Cochrane, A. L., Gilson, J. C., and Wood, C. H. (1959). Briz. 7. industr. Med., 16, 255.

Hill, A. B. (1965). F. roy. statist. Soc., Ser. A, 128, 256.

Holland, W. W., Reid, D. D., Seltser, R., and Stone, R. W. (1965). Arch. environm. Hlth, 10, 338.

Kissen, D. M. (1965). Med. Offr, 14, 344

Lawther, P. J. (1961). In The Air we Breathe, edited by S. M. Farber and R. H. L. Wilson. Thomas, Springfield, Illinois.

Mills, C. A. (1960). Amer. f. Med. Sci., 239, 316.

Mitchell, R. S., Vincent, T. N., and Filley, G. F. (1964). F. Amer. med. Ass., 188, 12 .

Ogilvie, A. G., and Newell, D. J. (1957). Chronic Bronchitis in Newcastle upon Tyne. Livingstone, Edinburgh.

Passey, R. D. (1962). Lancet, 2, 107.

Registrar-General (1958). Decennial Supplement, England and ales 1951. Occupational Mortality, Part II, vol. 1. H.M.S.O., London

Reid, D. D., and Fairbairn, A. S. (1958). Lancet, 1, 1147.

Anderson, D. O., Ferris, B. G., and Fletcher, C. M. (1964). Brir. med. F., 2, 1487.

Royal College of Physicians (1962). Smoking and Health. Pitman, London. 
Stocks, P. (1958), A.R. Brit. Emp. Cancer Campgn 1957, 35, Suppl. to Part II, p. 496.

Todd, G. F. (1966). The Reliability of Statements about Smoking Habits : Supplementary Report. Tobacco Research Council Research Paper No. 2A. London.

and Laws, J. T. (1959). The Reliability of Statements about Smoking Habits. Tobacco Manufacturers' Standing Committee Research Paper No. 2, 2nd ed. London.

Tokuhata, G. K. (1964). Amer. F. publ. Hlth, 54, 24.

T. and Lilienfeld, A. M. (1963). Publ. Hlth Rep. (Wash.), 78, 277.

U.S. Committee on Interstate and Foreign Commerce House of Representatives (1965). Cigaret Labeling and Advertising Act. U.S. Government Printing Office, Washington.
U.S. Senate Committee on Commerce (1965). Cigaret Labeling and Advertising. U.S. Government Printing Office, Washington.

U.S. Surgeon General's Advisory Committee (1964). Smoking and Health. U.S. Department of Health, Education, and Welfare, Washington.

Wicken, A. J. (1966). Tobacco Research Council Research Paper No. 9. London. In press.

and Buck, S. F. (1964). Report on a Study of Environmental Factors Associated with Lung Cancer and Bronchitis Mortality in Areas of North East England. Tobacco Research Council Research Paper No. 8. London.

Wynder, E. L., Lemon, F. R., and Mantel, N. (1965). Amer. Rev. resp. Dis., 91, 679.

\title{
Further Isolations of Reovirus Type 3 from Cases of Burkitt's Lymphoma
}

\author{
THOMAS M. BELL, $§$ B.SC., PH.D.; A. MASSIE,* $\|$ A.I.M.L.T.; M. G. R. ROSS,* B.SC. \\ D. I. H. SIMPSON, $\dagger$ M.B., B.CH., B.A.O. ; E. GRIFFIN, † F.I.M.L.T.
}

Brit. med. F., 1966, 1, 1514-1517

The attempted isolation of viruses from human tissue specimens has so far proved remarkably unrewarding. It is only from excised tonsils, adenoids, and lymph nodes that isolations have readily been obtained (Rowe et al., 1953, 1956 ; Bell and Steyn, 1962 ; McAllister et al., 1963). Viruses have also been recovered from the kidneys of children collected post mortem (BenyeshMeinick et al., 1964), from certain transplantable tumours (Moore, 1962), and from salivary glands (Smith, 1956). In every case, though it has proved possible to isolate an occasional virus from the homogenized tissue, a high recovery rate is obtained only when the tissue itself is cultured. The viruses isolated from these tissues have fallen into several groups, though the majority have been adenoviruses and herpesviruses. In addition to herpes simplex itself, varicella virus and several cytomegaloviruses have been recovered. A few strains of picornaviruses and at least one myxovirus-measles-have also been found. The remaining viruses are the $H$ strains isolated from transplantable tumours, which may be members of the papovavirus group, or belonging to the $\varnothing \times 174$ group of bacteriophages (Andrewes, 1962 ; Payne et al., 1964).

Several viruses have been demonstrated in tumour tissue excised from cases of Burkitt's lymphoma (Burkitt, 1962). From cases collected in Uganda six strains of herpes simplex have been isolated (Woodall et al., 1965 ; Simons and Ross, 1965), while a herpes-like virus has been demonstrated by electron microscopy in cultures of the tumour cells (Epstein et al., 1964 ; Stewart et al., 1965) and in direct biopsy material (Allbrook et al., 1966). Six agents, as yet unidentified, have been isolated from cases in Kenya (Dalldorf and Bergamini, 1964). The isolation of a single reovirus has already been reported by this group (Bell et al., 1964), and the present paper deals with the identification of this virus and its isolation from another eight cases in Uganda.

\section{Methods and Materials}

Between November 1963 and December 1964 tumour biopsy specimens were collected from 24 cases of Burkitt's lymphoma at Mulago Hospital, Kampala ; from two cases at the Freda

- Imperial Cancer Research Fund, P.O. Box 193, Entebbe, Uganda. † East African Virus Research Institute, P.O. Box 49, Eniebbe, Uganda. \# Department

Leverhulme Trust Research Fellow.

if Leverhulme Trust Research Associate.
Carr Hospital, Ngora, Uganda ; and from five cases at the Regional Hospital, Mwanza, Tanzania. Maitland-type cultures of all biopsies were set up in 6-cm. plastic Petri dishes with media $A, C$, and $L$. In some cases explant cultures were prepared in stationary tubes with a fowl plasma clot fed with medium C (Bell and Steyn, 1962). Sheets of fibroblasts which grow from these cultures were passaged, $0.25 \%$ trypsin (Difco $1: 250)$ being used. Media A and C consisted of Hanks's BSS plus $2 \%$ (A) or $20 \%$ (C) calf serum and $0.5 \%$ LAH. Medium $\mathrm{L}$ was prepared from Eagle's $\mathrm{MEM}$ plus $0.2 \% \mathrm{NaHCO}_{3}$ and $0.03 \%$ glutamine.

The suspensions of lymphoblasts which grew out from the biopsies were inoculated into tube or plate cultures of human embryo kidney (H.E.K.), human embryo lung (H.E.Lu.), Grivet monkey kidney (M.K.), or hamster kidney (Ham. K.) cells. Similarly, culture fluids from the fibroblast and explant cultures were inoculated in aliquots of $0.2 \mathrm{ml}$. per tube and $0.5 \mathrm{ml}$. per plate. Finally, tissue fragments from each tumour were inoculated direct into cultures of M.K. or H.E.K. cells. Most inoculated cultures were maintained in medium L. Control cultures were maintained from each batch of cells until natural degeneration occurred. Specific degeneration did not occur in any control cultures, only end-of-life degeneration.

Antiserum was prepared in rabbits against the CAN 230 strain as described previously for E.C.H.O. viruses (Bell, 1962). Neutralization tests were carried out by mixing $0.25-\mathrm{ml}$. aliquots of serial twofold dilutions of serum with $0.25 \mathrm{ml}$. of virus dilution in medium $A$ to give a final concentration of 100 $\mathrm{TCD}_{50}$ of virus per $0.2 \mathrm{ml}$. of mixture. The serum and virus were incubated for one hour at $34^{\circ} \mathrm{C}$. before inoculating 0.2 $\mathrm{ml}$. into two tubes of M.K. cells.

The prototype strains of reovirus types 1,2 , and 3 were kindly supplied by Dr. A. D. Macrae, Central Public Health Laboratory, Colindale, England.

Material was prepared for examination in the electron microscope as follows. Confluent monolayers of M.K. cells in 10-cm. Petri dishes were infected with the prototype strain of reovirus type 3 or two of the isolated strains-CAN 228/2 or CAN 230. When $50 \%$ of the cells showed a cytopathic effect the monolayer was removed with $0.25 \%$ trypsin and the resulting cell suspension was fixed in $5 \%$ gluteraldehyde and post-fixed in Palade's buffered osmic acid before spinning down to form a solid pellet. The pellet was embedded in Araldite after dehydration, sectioned, stained in uranyl acetate in $50 \%$ alcohol, and examined in a Zeiss EM9 electron microscope. 